\title{
Functioning of Children's Theaters in Russia (Repertoire Problems)
}

\author{
Evgeniia Dudkina, ${ }^{1, *}$
}

${ }^{1}$ State Institute of Art Studies, Moscow, Russia

*Corresponding author. Email: dudkinaea@mail.ru

\begin{abstract}
A lot of research, based on the analysis of both statistical and sociological data is devoted to the problems of the functioning of theaters of various genres. The purpose of this study is to analyze the repertoire policy of children's theaters in Russia in recent years. The work used the statistical data of the Ministry of Culture of Russia for the period 2016-2018 years. The article considers the problems of the functioning of children's theaters in modern Russian reality, as well as how the existing repertoire policy affects the development of moral and artistic standards of young viewer. The main conclusion of the study is that the repertoire of children's theaters has been practically unchanged for decades.
\end{abstract}

Keywords: theaters of young audience, children's theaters, puppet theaters, repertoire, statistics, education,

leaders of the repertoire

\section{INTRODUCTION}

There is a large choice of various forms of leisure activities, including cultural ones in the modern society. Not only such classical cultural institutions as theaters, philharmonics, museums and galleries, libraries, but also multifunctional cultural centers are fighting for the average visitor, giving him an opportunity to join both modern forms of art and amateur cultural creativity.

It should be noted that one of the most important functions of culture is educational. So, as we are talking about the younger generation, we should talk about the educational function of art. Moreover, about the possibilities of "living" forms of art. We have to agree that the events of recent months have shown great interest in theater, concert and museum activities. Thanks to the possibility of online views of theatrical performances, concerts of classical music and other materials, a significant part of the potential audience got the opportunity to join these types of art. But even here we are faced mainly with digital content intended more for the adult audience, already interested viewer. For example, The Bolshoi Theater during the period of isolation provided the opportunity to watch such famous productions as: "Swan Lake", "Sleeping Beauty", "The Tsar's Bride", "Marco Spada", "Boris Godunov", "Nutcracker". In my opinion, these performances are more intended for an adult audience, since they are quite complex for children's perception. For children at the same time, educational programs, films, animated films, computer games are mainly offered.
We can see that the Internet cannot properly replace live communication with art. Theater is not only a viewing of the performance, but also an introduction to theatrical culture, to the culture of perception and to the culture of behavior in society.

We can say that the theater art is one of the most important for the development of children and teenagers, together with museums, concert organizations and libraries. Of course, we cannot overestimate the influence of children's libraries and children's educational centers as an educational factor, but in fact only children's theaters are able to create the necessary concentration of artistic, aesthetic, educational and moral tasks at the same time.

The creation of the system of theaters for children and youth, and puppet theaters designed to carry out an educational and aesthetic mission was one of the achievements of the Soviet era that we have inherited. At that time, the presence of high-quality acting, directing and pedagogical staff, as well as a highly artistic approach to creating performances for children, provided a solid foundation for the development of theater for children in Russia. Unfortunately, by the mid-1980s, experts noted a crisis in the creative activities of these theaters [1].

Similarly, the problem of state financing, which is relevant for the entire sphere of culture, is more relevant than ever for the already small network of children's and youth theaters. This is an area that cannot and should not survive due to increases in ticket prices and constantly search for independent sources of financing. The main task of the theater for children is to 
attract its audience, the possibility of choosing a modern repertoire that can interest this audience, educate the future theater audience.

But even decades after the economic recession of the 1990s, the problem of underfunding of theaters for children and youth, which is especially relevant for the regions, as well as the lack of a structured repertoire policy, is still taking place. As in previous years, there is a lack of modern dramatic works intended directly for children. Tales intended for primary school age are still the basis of the repertoire of children's theaters, and there are practically no works intended for teenagers. Thus, the theater is somehow eliminated from its educational function.

At the same time, it should be noted that in the "Fundamentals of State Cultural Policy" [2], special attention is paid to the fact that the creation of a developed network of theater, concert and exhibition halls is one of the priority directions, and the necessary condition for the development of Russia is the maximum involvement of the potential of culture in the processes of social progress. And in the "Fundamentals of the State Youth Policy of the Russian Federation for the Period until 2025" (dated November 29, 2014 No. 2403-r), in turn, among the goals and priority tasks of the State youth policy are indicated such as: "involvement of youth in creative activities, support for young artists, as well as talented youth" [3].

\section{THEATERS FOR CHILDREN IN STATISTICS}

A large number of researches based on the analysis of statistical and sociological data is devoted to the problems of the functioning of theaters of various genres. The statistical data of the Ministry of Culture of Russia (by GIVC of the Ministry of Culture of Russia) [4] provides the following separation: opera and ballet theaters, musical comedy theaters, dramatic theaters, young audience theaters, puppet theaters and others. Thus, according to statistics, in 2018 in the Russian Federation there were 657 theaters of all departments (including theaters of the Ministry of Culture of Russia). From these, we can separate 75 theaters for children and young audience and 109 puppet theaters.

During the decades that have passed in Russia since 1991, much has changed, both in the economy of the social sphere and in the theater life. The network of theaters, including theaters for young audience and children, the puppet theaters, etc., has decreased and increased again and again. However, there are still some regions in which there were no such theaters at all.

For comparison, from 1990 to 2000, the number of theaters for children and young audience increased from 35 to 52 units, and the number of puppet theaters from 81 to 99 , though in the following republics:
Adygea, Altai, Ingushetia, Kalmykia, KarachayCherkessia and in the Novgorod region for all this time no one puppet theater exists at all [5].

Next, we turn to the statistics of recent years.

In 2016, according to the statistical data of the Ministry of Culture of Russia, there were 75 theaters for young audience and children, and 108 puppet theaters (of all departments, including federal and local subordination), however there were no theaters for young audience and children in 36 regions of the Russian Federation. Of course, it should be understood that in such cases, part of the functions of children's theaters are redistributed to drama theaters and other theaters in which there is a repertoire intended for children and teenagers. However, we must not forget that there are still regions where theaters of any kind are absent at all.

The situation with the puppet theaters is slightly better. According to data of 2016, they are absent in only 13 regions of Russia.

Also, we should note, that the number of buildings, their safety and capacity, as well as the number of employees, are usually much less for children's theaters and puppet theaters than the same indicators in drama theaters.

And by now, the situation with the number of children's theaters has not improved. According to the statistical data of the Ministry of Culture of Russia [6] in 2018, there were 75 theaters for young audience of all departments (at the same time, there were 71 theaters of the systems of the Ministry of Culture of the Russian Federation: 1 - by federal administration, and 70 by local administration). If we talk about puppet theaters, then their number was 109 (of all departments) (108 theaters of the systems of the Ministry of Culture of the Russian Federation, i.e. 1 - by federal administration and 107 by local administration).

Speaking about the activities of children's theaters and puppet theaters of the Russian Federation, we also should tell about the general characteristic of the theater network of the Russian Federation. Because we use the statistics of the Ministry of Culture of Russia, we should take into account only the state theaters, so, as a rule, those theaters that do not give any information about them, the unregistered theaters, the private theaters, etc. do not account here.

Consider the main indicators, such as the network (number of theaters), the number of buildings, the commercial capacity of halls and the number of workers in theaters in total, and separately - in opera and ballet theaters, musical comedy, drama, children's theaters and puppet theaters for 2016 and 2018. The tables contain data on theaters of the Ministry of 
TABLE I. NETWORK OF THEATERS OF THE MinistRy OF CULTURE OF RUSSIA, 2016

\begin{tabular}{|c|l|l|l|l|l|l|l|}
\hline Indicators & \multirow{2}{*}{$\begin{array}{c}\text { Theaters } \\
\text { (all) }\end{array}$} & \multicolumn{6}{|c|}{ Including } \\
\cline { 3 - 8 } & & $\begin{array}{c}\text { Opera and } \\
\text { ballet }\end{array}$ & $\begin{array}{c}\text { Musical } \\
\text { comedy }\end{array}$ & Drama & Children's & Puppet & Others \\
\hline Network & 613 & 74 & 10 & 330 & 72 & 107 & 20 \\
\hline Number of buildings & 1332 & 284 & 29 & 690 & 124 & 174 & 31 \\
\hline $\begin{array}{c}\text { Commercial capacity } \\
\text { of halls }\end{array}$ & 265455 & 52576 & 7982 & 151649 & 26303 & 21324 & 5621 \\
\hline Number of workers & 86596 & 27698 & 3100 & 40520 & 7117 & 6688 & 1473 \\
\hline
\end{tabular}

a. The table was built by the author of the article according to the GIVC. Theaters of the Russian Federation in numbers. 2016 // Ministry of Culture of the Russian Federation Main Information and

In addition to the problems associated with the lack of children's and youth theaters, as well as puppet theaters in some regions, we can see the problem of underfunding of theaters for children and youth, as well as the problems related to the formation of a repertoire.

In 2016, there are 127 buildings for 75 children's theaters (all departments), 33 of them requiring capital repairs, and 3 are in critical condition. If we talk about puppet theaters, we can see that the situation here is almost the same. There are 175 buildings for 108 theaters included in the statistical data, 39 of them require capital repairs and 3 are in critical condition.

According to data for 2018 (theaters of all departments), there are 127 buildings for 71 children's theaters, 37 of them requiring capital repairs, and 4 are in critical condition. For the puppet theaters the situation is also the same. There are 176 buildings for 108 theaters included in the statistical data, 45 of them require capital repairs and 1 is in critical condition.

TABLE II. NETWORK OF THEATERS OF THE MiNISTRY OF CULTURE OF RUSSIA, 2018

\begin{tabular}{|c|c|c|c|c|c|c|c|}
\hline \multirow[t]{2}{*}{ Indicators } & \multirow{2}{*}{$\begin{array}{c}\text { Theaters } \\
\text { (all) }\end{array}$} & \multicolumn{6}{|c|}{ Including } \\
\hline & & $\begin{array}{c}\text { Opera and } \\
\text { ballet }\end{array}$ & $\begin{array}{l}\text { Musical } \\
\text { comedy }\end{array}$ & Drama & Children's & Puppet & Others \\
\hline Network & 619 & 75 & 9 & 337 & 71 & 108 & 19 \\
\hline $\begin{array}{c}\text { Number of } \\
\text { buildings }\end{array}$ & 1428 & 383 & 19 & 695 & 127 & 176 & 28 \\
\hline $\begin{array}{c}\text { Commercial } \\
\text { capacity of halls }\end{array}$ & 271539 & 54140 & 7355 & 156100 & 26200 & 21871 & 5873 \\
\hline Number of workers & 86925 & 28885 & 2721 & 40056 & 7162 & 6683 & 1418 \\
\hline
\end{tabular}

The table is built by the author of the article for the purposes of this study on the materials: Statistics on the types of institutions of culture, art and education 2018", URL: https://stat.mkrf.ru/indicators/ (date of access: 30.11.2019)

Based on these data, we can understand that the material base of children's theaters and puppet theaters is only worsens. An increasing number of buildings require capital repairs, though we are talking about theaters for children, perfectly understanding that higher safety equipment is required here as nowhere, and it is quite difficult to talk about the aesthetic perception of the performance in the collapsing building!

Now we talk about the income of theaters in general, and of children's theaters, in particular. The largest share in the income of the theater is still the budget part. In 2018, the income of children's theaters amounted to $6,164,2$ million rubles, while the share of budget financing was about $89 \%$ (for puppet theaters $6,094,7$ million rubles, with the share of budget financing $-80 \%$ ), and the cost of wages in the total share of expenses amounted to $58 \%$ (for puppet theaters - 56\%). For comparison - in 2016, the share of budget funding for children's theaters was about $70 \%$, and for puppet theaters $-75 \%$. More than $55 \%$ of the expenses of children's theaters in 2016 were salary, in puppet theaters - about $58 \%$.

If we talk about such indicators as the purchase (replacement of equipment) - in 2016 they accounted for less than $5 \%$, as well as the share of costs for new productions - amounted to $5 \%$ of the total costs of theaters. In 2018, the situation became slightly better. The share of such part of expenses as the purchase (replacement of equipment) accounts 6\%, and for new productions $-7 \%$.

If we analyze similar indicators for puppet theaters, then we get that the purchase (replacement of equipment) in 2016 accounted about $2 \%$ of the total cost, and for new productions $-3 \%$ of the total cost of theaters. In 2018, these indicators amounted to $8 \%$ and $5 \%$, also showing some improvement.

Of course, it should be understood that this is an absolutely average indicator. Funding and the existence 
of theaters in Moscow and St. Petersburg is fundamentally different, that in other regions of Russia.

\section{PROBLEMS OF REPERTOIRE FORMATION}

Despite some improvement in the situation with the financing of new productions, the problem of outdated repertoire still remains urgent. Modern children visit almost the same performances as their parents in the past.

And the point is not only that there are no new productions in the repertoire of theaters, but that the same plays remain the leaders of the repertoire for many years.

The problem of forming a repertoire designed specifically for children is not new. But unfortunately, the same names of dramatic works intended for children flow from the poster of one year to another almost unchanged.

At the same time, it should be noted that the share of events for children of different age groups is not equal. In addition, we can see another trend - a significant advantage in the repertoire falls on the performances for a group of children of the younger age group.

Of course, we would like to determine which plays (productions) are most popular. But unfortunately, statistics do not provide such an opportunity. What can we see?

They separate (in the statistics the Ministry of Culture of Russia) the following positions: works on historical and national grounds by Russian modern authors (since 1992); by authors of near abroad of the soviet period; by authors of near abroad (since 1992); by Russian classics authors; by soviet national authors; by Russian national authors; by foreign contemporary authors; by foreign classics authors.

In my opinion, such a gradation is outdated and cannot give a full picture of what is really happening to the repertoire. And since all these data are obviously averaged, it is difficult to make fully justified conclusions. So, it must be understood that each individual theater can have its own repertoire policy, both quite successful and vice versa. ("Fig. 1", "Fig. 2")

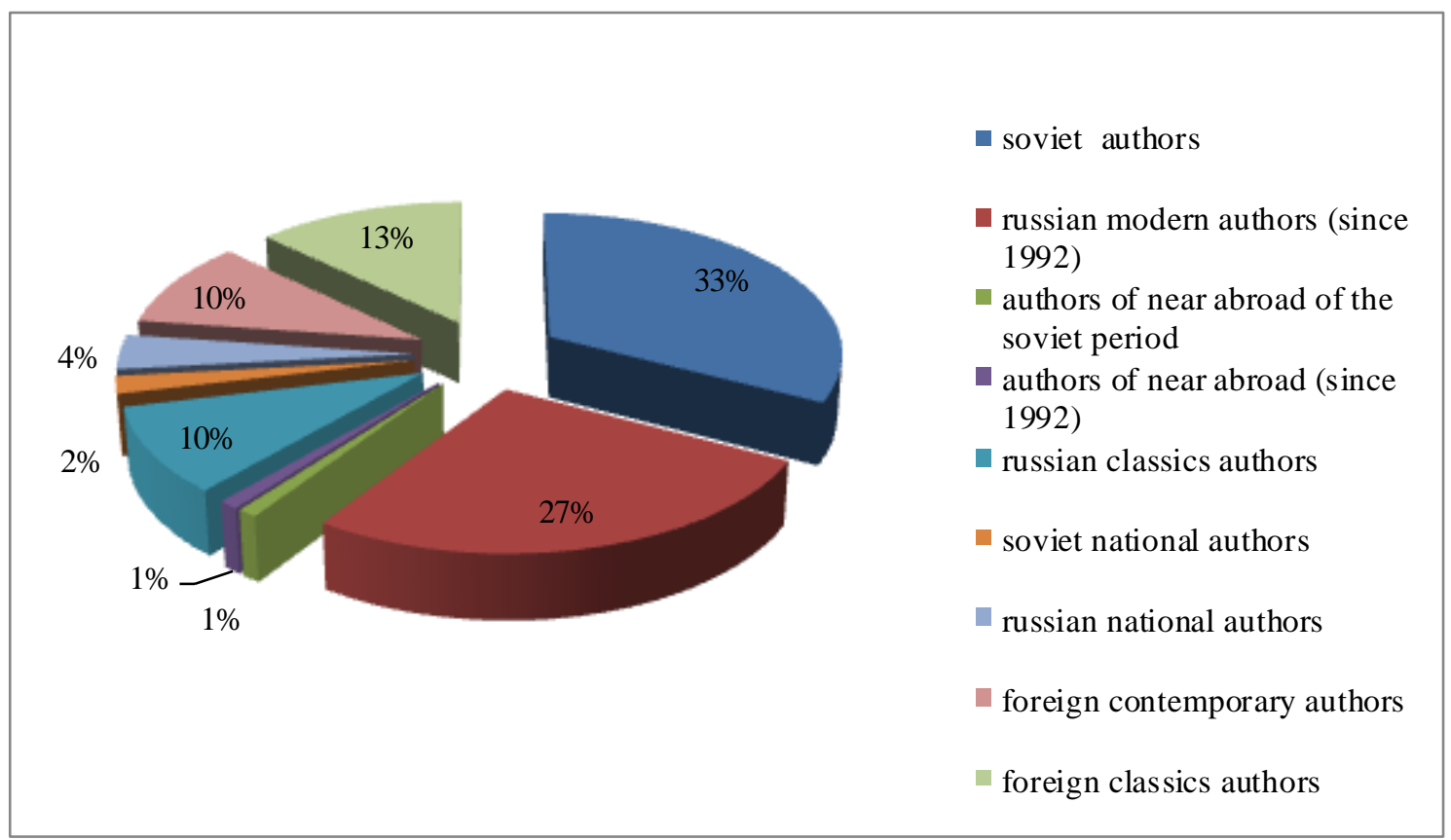

Fig. 1. Repertoire of children's theaters by the number of performances in $\%, 2016$.

a. The figure was built by the author of the article according to the GIVC. Theaters of Russign Federalon in

The largest share remains on the works of soviet authors and Russian modern authors (since 1992). It would seem good that the share of modern authors is growing (if you compare the graphics). However, already in this definition, lies the fact that the works Information and Computing Center, Moscow 2017 from 1992 are considered modern, and by now the age of these works has reached more than 25 years, that means, that the children are still doomed to go to the same performances as their parents. 


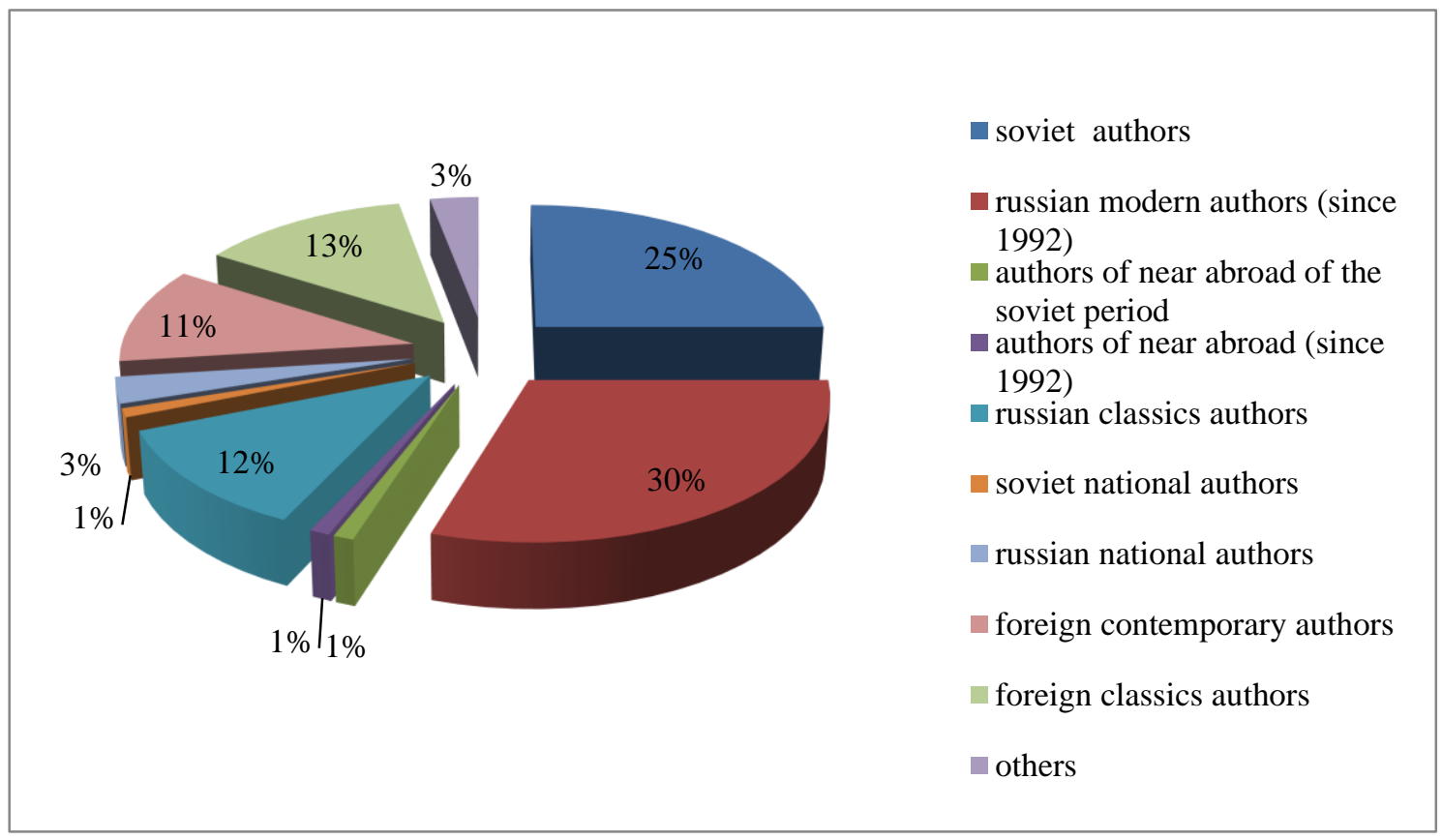

Fig. 2. Repertoire of children's theaters by the number of performances in $\%, 2018$.

a. The figure is built by the author of the article for the purposes of this study on the materials "Statistics on the types of institutions of culture, art and education 2018," URL https://stat.mkrf.ru/indicators/ (date of appeal 30.11.2019).

Summing up the preliminary results we can say: most of the performances and a large share of visits in children's theaters belongs to the works of soviet authors, Russian and foreign classics. The share of works by soviet and Russian national authors is very insignificant in the total volume of performances and the repertoire of theaters, that is $-1 \%$ and $3 \%$ in 2018 ( $2 \%$ and $4 \%$ in 2016). At the same time, I would like to pay attention to the fact that children's theaters exist not only in the center, but also in the regions. Thus, there is an unused opportunity to increase the share of works by national authors in the repertoire of national theaters.

If we summarize these data, we will get the share over than $60 \%$ of the works that are in the modern repertoire, but created in the last century. There are practically no performances based on the plays of national authors.

I would note that with the existing classification of the repertoire into categories, it is very difficult to understand how modern the play is. For this you need to have not averaged data, but information on each particular theater and repertoire name.

Next, we will conduct a more detailed analysis of the modern repertoire, which allows us to distinguish the leaders of the repertoire, as well as analyze its structure. In a more detailed analysis of the repertoire of children's theaters, we will consider which plays are the leaders of the modern repertoire.
Running forward, I want to note the existence of a strong distortion in favor of plays for preschool and elementary school age, and relatively few works for youth. Moreover, the basis of the repertoire of these theaters is fairy tales, performances for children, focused on the holiday and New Year themes.

The following comparative data for 2016 were obtained on the basis of the analysis of the statistical form "Code of 9-HK (repertoire) for 2016". During the work statistical data were analyzed for all regions of the Russian Federation (the repertoire of children's theaters and puppet theaters (the repertoire of drama, music and other theaters was not taken into account). In addition, it should take into account that the number of names of the repertoire (all regions), the combined repertoire amounted to more than 300 titles (313), some of which are repeated many times. It should also be noted that in some cases performances with the same name belong to the pen of various authors, and therefore they stood out as an independent work.

The next step was the allocation of repertoire leaders for various age groups of visitors: preschool age, primary school age, secondary school age and youth.

For the first group - "Leaders of the repertoire for preschool children" - from more than 300 titles of the repertoire, seven plays were allocated, which are the most popular. These are such plays as "The Cat's House" and "Teremok" by S. Marshak, "The Little 
humpbacked Horse" by P. Ershov, "The Canterville ghost" of O. Wilde, "Little Red Riding Hood", as well as interactive performances (i.e. some fabulous fantasy performance without an author). In addition, New Year's performances for babies are very popular.

Summarizing the analyzed list of productions, it should be noted that almost all the plays presented in it are productions based on famous fairy tales $(99 \%$ of the repertoire), which were made, as a rule, about fifty years ago. And there are practically no works of modern playwrights.

The second group is the "Leaders of the repertoire for children of primary school age". In first place is the "New Year's Performance" (various authors) - was in the repertoire of 29 theaters. In the next place is the play "Golden Chicken" by V. Orlov (13 theaters), then - "Puss in Boots" by Ch. Perrault (in 13 theaters), "Russian folk tales" (in 13 theaters), "The Scarlet Flower" by S. Aksakov (present in the repertoire of 11 theaters), "Birthday of Cat Leopold" (in 10 theaters). If we talk about the genre of productions, then these are still fairy tales related to foreign and Russian classics or Russian folk tales.

Next, we propose to turn to the analysis of the repertoire for secondary school age and youth - in the total repertoire of children's theaters these are about $9 \%$ -114 productions (by list).

Summarizing the data, we can say that in addition to the tales (a little more than $40 \%$ in the repertoire of theaters), we can also note the appearance of theatrical concerts, comedies, musicals, dramas, tragedies, chronicles, comedies and tragicomedy, musical dramas, musical comedies, chamber operas and ballet. The repertoire is growing up, becoming closer to the repertoire of drama theaters, but in the leaders, still stay fairy tales and interactive performances.

The group "Leaders of the repertoire for children of secondary school" included: "The Nutcracker and the Mouse King" ("Princess Pirlipat") by E. Hoffmann (in the repertoire of 17 theaters), then - "Cinderella" by E. Schwartz (in 10 theaters), at the same level is "Tom Sawyer", a staging of the work of M. Twain (in 10 theaters), then the fairy tale "Little Prince" by A. Exupéry (in 8 theaters).

The group "Leaders of the repertoire for youth" included: a staging of A. Grin's novel "Scarlet Sails" ("And the Fresh Breeze Filled Sails") - (in 7 theaters), in the second place - the drama "Maryino Field" ("Journey along the Edge") O. Bogaev (in 4 theaters), and "An Ordinary miracle" (in 4 theaters). In genre terms, a fairy tale practically leaves the repertoire for youth - it is replaced by dramas, melodramas, staging of works of art, musicals, chronicles, comedies and tragicomedy, etc.
As we can see, there are practically no plays that previously appeared in the repertoire. And if we correlate the average indicators of the number of theaters with the number of names in the repertoire, then we actually get one performance for youth for one theater of a young audience or a children's theater.

Unfortunately, there are no available statistics for all of the above groups for 2018. But I can give some general data on the leaders of the repertoire for children's theater in 2018. Here we can see the following regularity. In first place - "The Nutcracker and the Mouse King" by E. Hoffmann- 16 productions, "Puss in Boots" - Ch. Perrault - 14 productions, "Golden Chicken" by V. Orlov - 14 productions, "Little Thumbelina" by G.-H. Andersen- 12 productions, "The Little Humpbacked Horse" by P. Ershov. Continuing the list we can note " Cat's House" by S. Marshak, "The Scarlet Flower" by S. Aksakov, "Cinderella" by Ch. Perrault, "The Tale of Tsar Saltan" by A. Pushkin. Even with a close comparison, we can say that these lists nearly repeat the lists of 2016 .

It seems difficult to make the concrete conclusions based on a small time period (2016-2018 years). But now I will quote several phrases from the study of 2007 on the repertoire policy of children's theaters: "By the mid-80s.... A solid place in the leaders of the allRussian poster in the number of productions and performances was taken place such works as "The Three Little Pigs", "The Scarlet Flower", "Puss in Boots", "Goose", "Golden Chicken", "The Adventures of Buratino", "Buka", "Little Fairy", "Little Red Riding Hood", "Cinderella"... The tendency of deformation in the children's theater audience, which showed in the 70-80s. of last century, continued to develop. The poster of children's theaters is increasingly filled with works for preschoolers and children of primary school age, and accordingly repertoire offers for adolescents and youth are reduced...

It is obvious that the rejection of adolescents and youth from the theatrical audience continues to develop, and the theatrical community has not yet found ways to overcome it" [7].

Why do I quote those words? If we once again look at the modern poster of children's and puppet theaters, then like decades ago, among the leaders of repertoire we will see almost the same list of plays.

Analyzing the modern repertoire of children's theaters, we are involuntarily transferred to the last century, and now we can wonder: where the works of modern authors are? Of course, there is nothing wrong in the tales of A. Pushkin, Ch. Perrault, A. Tolstoy, S. Marshak, K. Chukovsky and others, but it is worth thinking that modern children do not live in the world of the 80s. And what was interesting to their parents may not be such an exciting sight for them. Modern 
children brought up in another world and in other information conditions, they will be forced, due to the lack of modern repertoire, and the need to familiarize themselves with the classics of literature, which, unfortunately, is also extremely limited in the repertoire of children's theaters to come with their parents or as part of a school group to these performances, but who guarantees that such a representation will cause interest, but not rejection.

\section{Conclusion}

Numerous sociological studies of past years have confirmed the fact that than earlier a child became interested in art, including theater, the more likely he is to become a regular visitor to theaters, museums, etc. [8]. But where is the guarantee that the effect will not be reversed? The material base of many Russian children's theaters is in a rather bad condition, which means that in addition to the impossibility of providing a solid repertoire component, the theater cannot provide the appropriate artistic level. Performances for children require colorfulness and should attract their audience, give him a feeling of miracle.

Children's theater, first of all, should educate the younger generation, be a modern theater, and not the theater of our grandmothers, otherwise it risks losing its audience. Actually, this is what the pedagogical part should think about, but unfortunately, the situation has now developed in such a way that in many theaters it simply does not exist, and those who should perform these functions are most likely occupied with other problems.

\section{References}

[1] V. Dmitrievsky, "Children's Theater - Time of Trials" in: "Children and Culture", Moscow, KomBook, 2007, pp. 98-113.

[2] "Fundamentals of state cultural policy" (approved by Decree of the President of the Russian Federation of December 24, 2014 No. 808). URL: http://www.consultant.ru/document/cons_doc_LAW_172706/ (access date: 29.06.2020).

[3] "Fundamentals of the state youth policy of the Russian Federation for the period up to 2025" (dated November 29, 2014 No. 2403-r). URL: http://www.consultant.ru/document/cons_doc_LAW_171835/54 16a7ecef3afe3ff052deb74264bbf282e889ef/ (access date: 29.06.2020).

[4] AIS "Industry Statistical Reporting. URL: https://stat.mkrf.ru/ (access date: 29.06.2020).

[5] V. Dmitrievsky. op. cit.

[6] Statistics on cultural, arts and educational institutions, 2018. URL: https://stat.mkrf.ru/indicators/ (access date: 30.11.2019).

[7] V. Dmitrievsky. op. cit.

[8] Yu. Fokht-Babushkin, "Art in the life of people. (Specifically sociological studies of art in Russia in the second half of the 20th century. History and methodology)", St. Petersburg, Aleteia, 2001, 556 p. 